\title{
How the presence of a salt décollement in the sedimentary cover influences the behavior of subsalt thrusts in fold-and-thrust belts
}

\author{
Bruno C. Vendeville ${ }^{1, *}$, Tang Pengcheng ${ }^{1,2,3}$, Fabien Graveleau ${ }^{1}$, Huang Shaoying ${ }^{4}$ and Xin Wang ${ }^{2}$ \\ ${ }^{1}$ Univ. Lille, CNRS, Univ. Littoral Côte d'Opale, UMR 8187, LOG, Laboratoire d'Océanologie et de Géosciences, Lille 59000, France \\ 2 School of Earth Sciences, Zhejiang University, Hangzhou 310027, China \\ 3 Petrochina Hangzhou Research Institute of Geology, No. 920, Xixi Rd., WestLake District, Zhejiang, Hangzhou 310023, China \\ ${ }^{4}$ Exploration and Development Research Institute, Tarim Oilfield Company, PetroChina, Korla, Xinjiang 841000, China
}

\begin{abstract}
We conducted a series of analogue experiments on shortening of a brittle cover (dry sand) above a deep, thin, frictional detachment (glass microbeads). In some experiments, the cover was homogeneous, entirely brittle. In others, there was a thin viscous silicone layer (representing salt) embedded at mid height into the cover, and initially located in the foreland of the fold-and-thrust belt. Our goal was to determine whether or not the presence of such a décollement in the cover could have an impact on the mechanics and kinematics of the underlying subsalt thrusts. Results confirm that, once the front of the foldbelt reached the hinterland salt pinch out, the kinematics of the deeper belt changed drastically: its front stopped propagating forward, and most of the subsequent shortening was accommodated by a larger-than-normal slip along the foremost and youngest deep thrust, while, above the salt décollement, the deformation front propagated very fast, creating a very low surface slope. We hypothesize that it is the gentle sub-critical surface slope associated with rocksalt's low viscosity that prevents the build-up of an overall surface slope steep enough to allow the underlying, deep foldbelt to continue propagating forward. Finally, one experiment in which only one half of the width of the model comprised an interbedded viscous décollement has shown that the kinematics of the deep thrust was affected even in the adjacent salt-free domain.
\end{abstract}

Keywords: salt tectonics / fold-and-thrust belts / analogue modeling / décollement

\begin{abstract}
Résumé - Influence de la présence d'un niveau de décollement évaporitique situé au sein de la couverture sur l'évolution des chevauchements sub-salifères profonds lors de la propagation d'une chaîne d'avant-pays. Nous avons réalisé une série d'expériences de modélisation analogique étudiant le raccourcissement d'une couverture sédimentaire constituée de matériel fragile (sable sec) enracinée sur un niveau profond frictionnel (microbilles de verre), mais comprenant localement une couche visqueuse interstratifiée de plus faible résistance mécanique (polymère de silicone). Le but de ces expériences était d'analyser l'impact d'un tel niveau de décollement visqueux superficiel sur la mécanique et la cinématique des chevauchements de la zone profonde, et notamment sur les modalités de la transmission de la déformation entre les deux niveaux de décollement. Les résultats expérimentaux confirment bien que, lorsque le front de déformation profond atteint la région où se trouve la série visqueuse interstratifiée, la cinématique des chevauchements profonds change de façon drastique. Le front de déformation profond cesse de se propager vers l'extérieur du modèle, et le chevauchement profond le plus jeune se connecte avec le niveau de décollement superficiel. Ainsi, la plus grande partie du raccourcissement est transmise aux séries superficielles de la couverture. Le front de déformation migre rapidement vers l'extérieur en se propageant sur le niveau à faible résistance mécanique. La pente topographique critique du modèle change alors brutalement, passant de quelques degrés dans la zone frictionnelle interne à virtuellement zéro dans le domaine externe. Notre interprétation est que la pente topographique moyenne du système accrétionnel n'est plus suffisante, dès lors qu'il atteint la zone visqueuse, pour permettre à la déformation profonde de se propager vers l'avant. De fait, le système,
\end{abstract}

\footnotetext{
*Corresponding author: Cité Scientifique, Bâtiment SN-5, 59655

Villeneuve d'Ascq, France. Bruno.Vendeville@univ-lille1.fr
} 
passant en régime sous-critique, est forcé de stopper la propagation de la déformation profonde pour favoriser un épaississement des domaines internes, favorisant ainsi l'augmentation de la pente moyenne dans la zone interne. Enfin, une expérience a démontré que même quand la présence de cette couche visqueuse interstratifée était latéralement limitée, la cinématique des chevauchements adjacents en était aussi affectée.

Mots clés : tectonique salifère / chaînes d'avant-pays / modélisation analogique / niveaux de décollement

\section{Introduction}

It is not uncommon for a fold-and-thrust belt or an accretionary prism to reach, as it propagates toward the foreland, an area in which the sedimentary cover comprises an additional décollement made of evaporites (e.g., salt) or overpressured shale (Fig. 1). This is the case, amongst others, of the Southern and Northern Pyrenees in Spain and France (Vergés et al., 1992; Munoz, 2002; Serrano et al., 2006), the Kuqa Basin in China (Chen et al., 2004), the Mediterranean Ridge (Reston et al., 2002), or the Franklin Mountains in NW Canada (Aitken and Pugh, 1984; Morrell, 1995). In these examples, the thrusts affecting the deeper part of the series do not appear to have propagated much forward, even if the basal décollement extend all across, whereas the frontal basal thrust ramped up and connected within the overlying décollement. Meanwhile, the front of the thin-skinned suprasalt deformation propagated much faster and farther ahead. In the case of the Pyrenees, the deeper décollement pinched out southward and forward propagation of deformation occurred on the upper décollement (Vergés et al., 1992; Santolaria et al., 2015).

We undertook a series of systematic experiments in order to better understand how thick-skinned shortening could interact and, possibly, be influenced by shallow deformation above a silicone layer (to which, we will refer to as "salt" for sake of simplicity) embedded within the sedimentary cover. Similar experiments have already been published (Mugnier et al., 1997; Leturmy et al., 2000; Bonini, 2003; Duerto and
McClay, 2009), all of them focusing on how deformation at depth may influence the behavior of the salt and its sediment overburden. However, in the course of our experimental work, we discovered that the presence of salt in the sedimentary cover could, in turn, influence the kinematic evolution of the underlying thrusts sheets at depth. In this article, we present our experimental results, then we discuss the mechanical reasons on how and why such an influence can take place.

\section{Experimental design and procedure}

We designed a series of experiments specifically aimed at better understanding the impact of the presence of a salt layer on the evolution of the deeper thrusts. Here, we present only the three most significant ones. All models were made mostly of dry quartz sand (angle of internal friction: 30-34 $)$ (Klinkmüller et al., 2016) and had an initial length of $121 \mathrm{~cm}$, and an initial total thickness of $28 \mathrm{~mm}$ (lower and upper series) resting on a $2 \mathrm{~mm}$ thick layer of glass microbeads, which acted as a deep frictional basal detachment (Fig. 2). Some models included a salt-analogue layer (viscous silicone polymer SGM 36, having a viscosity of about $2 \times 10^{4} \mathrm{~Pa} . \mathrm{s}$ ) (Rudolf et al., 2016) embedded at mid height within the cover, whereas others did not. All models were deformed at a rate of $0.47 \mathrm{~cm} / \mathrm{h}$ (corresponding to about few $\mathrm{cm} / \mathrm{yr}$ in nature) until a total amount of shortening of $54.6 \mathrm{~cm}$ was reached $(55 \%)$.

The first two models (Models 1 and 2) were built in a cylindrical fashion. Model 1 comprised of only one single,

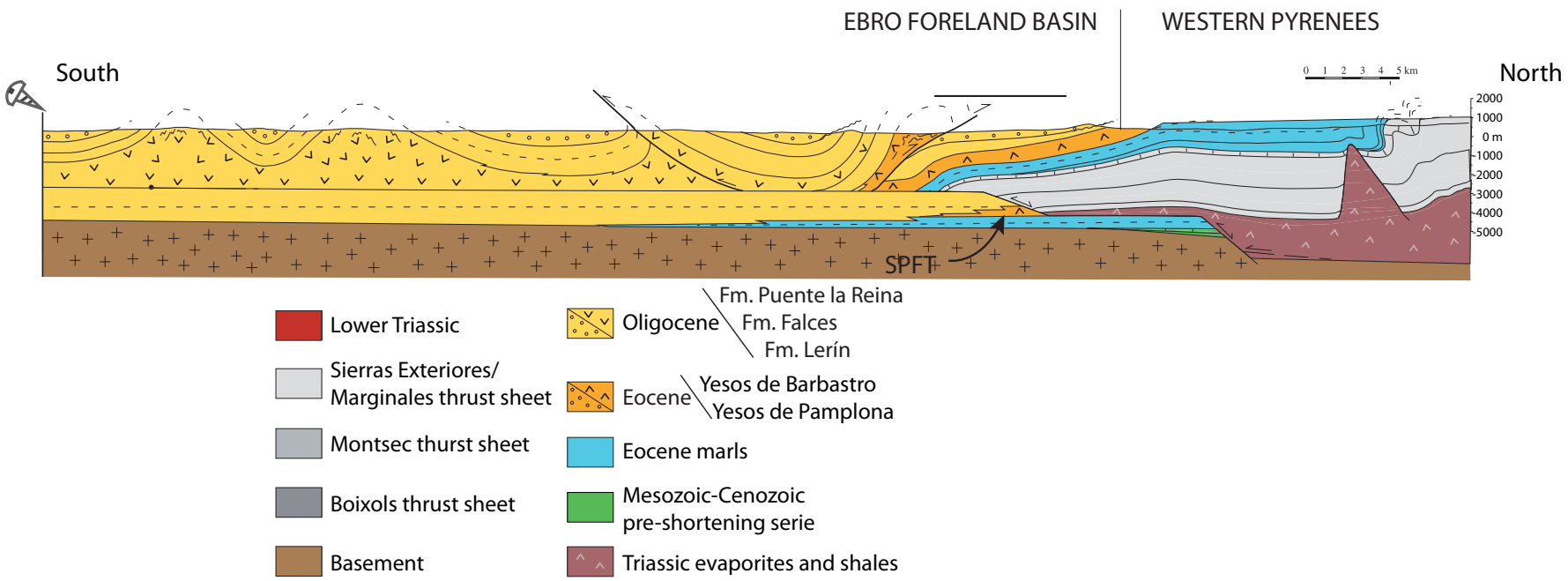

Fig. 1. Schematic N-S cross section across the Spanish Pyrenees by Larrasoaña et al. (2003), (modified by Santolaria et al., 2015) illustrating a deep-seated Triassic décollement branching out upward into a Eocene evaporitic level. 
(a) Model 1

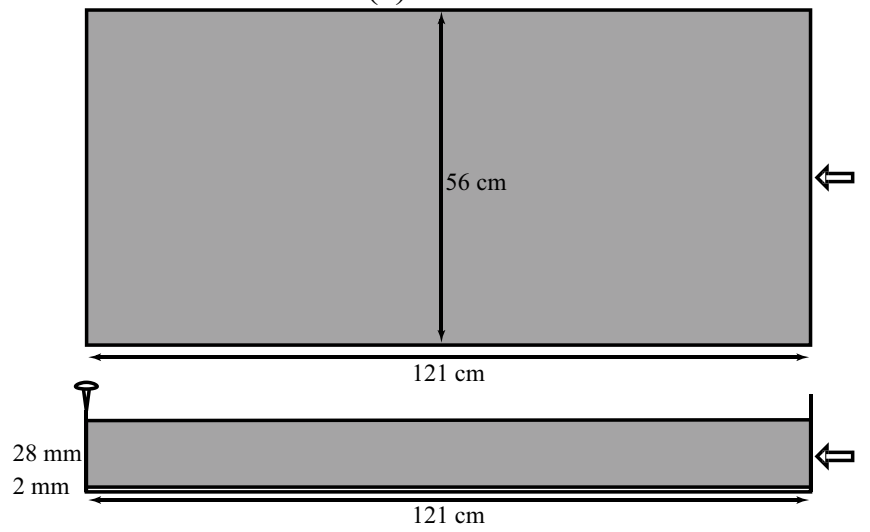

(b) Model 2

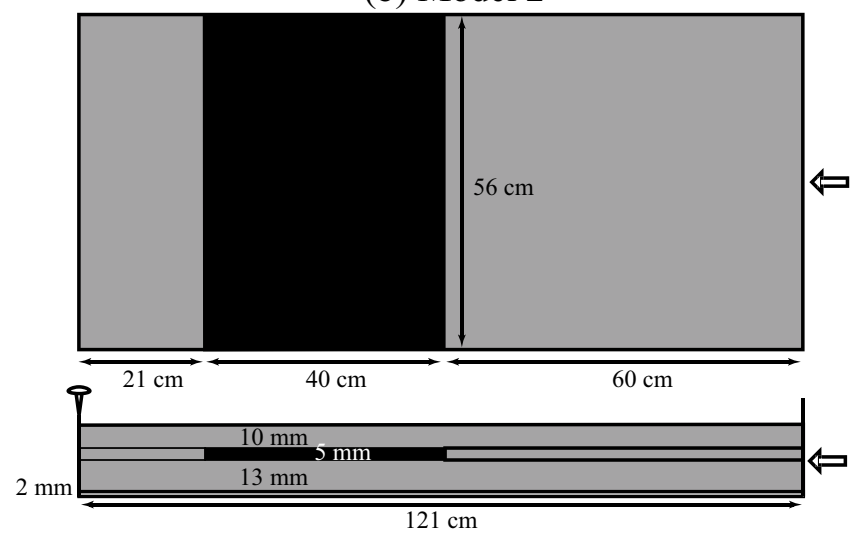

(c) Model 3
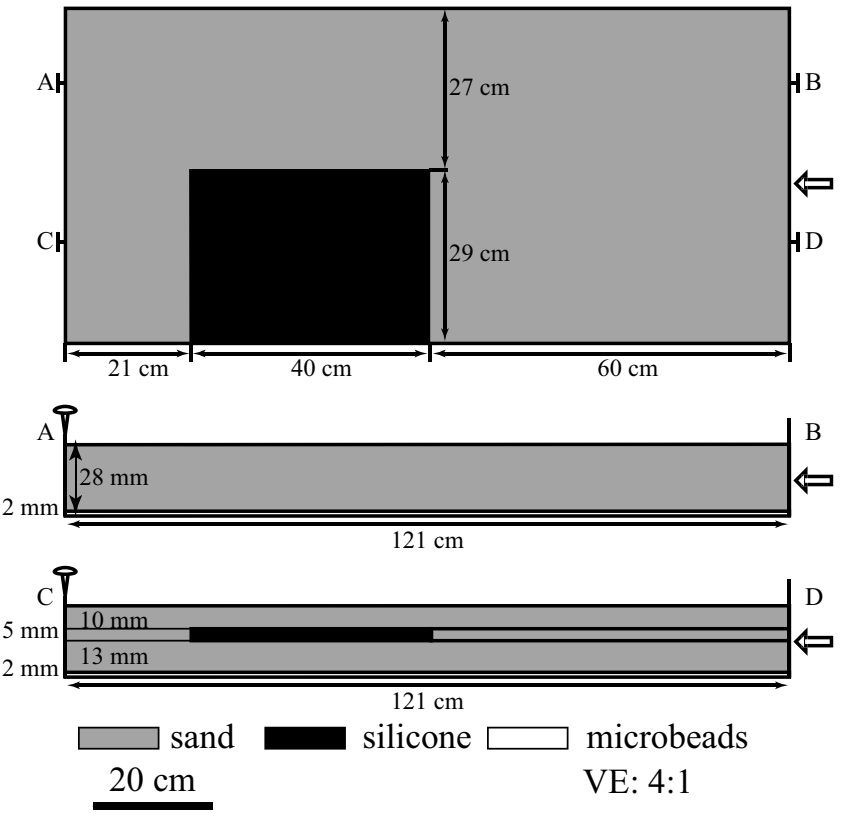

Fig. 2. Initial geometry of Models 1,2 and 3 . The cross sections are vertically exaggerated $4: 1$.

28-mm-thick layer of dry sand lying across the entire model (Fig. 2, top) overlying a $2 \mathrm{~mm}$-thick glass microbead-glass layer. Model 2 included a $5 \mathrm{~mm}$ thick layer of viscous silicone. This layer overlaid a 13-mm-thick lower sand layer and was

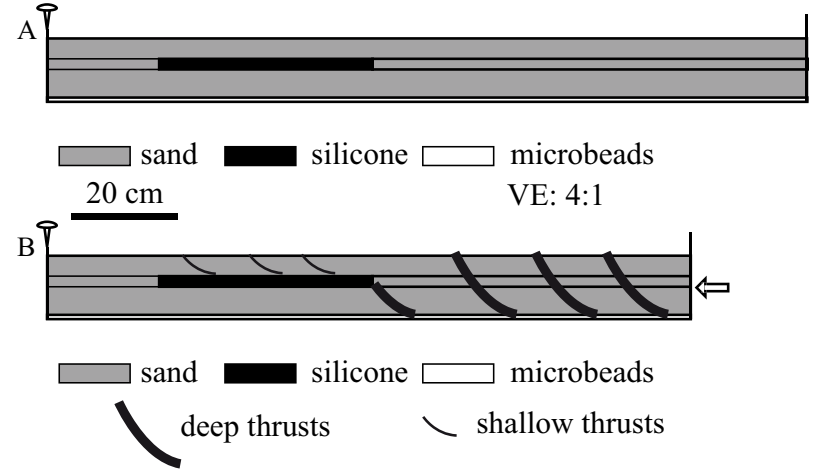

Fig. 3. Schematic cross sections indicating the terminology we use for deep and shallow thrusts in our discussion.

overlain by a $10 \mathrm{~mm}$ thick brittle sand cover (Fig. 2, middle). The viscous silicone layer covered only part of the model's length but lay all across the entire model's width (Fig. 2, middle). It is worth noting that previous models in the literature generally display boundary conditions in which an interbedded viscous level is in direct contact with the backstop at the initial stage (Guillier et al., 1995; Leturmy et al., 2000; Bonini, 2003; Sherkati et al., 2006; Nilfouroushan et al., 2012; Ruh et al., 2012). Very few experiments and numerical simulations started with a frictional domain between the backstop and the interbedded viscous level (e.g. Cotton and Koyi 2000, Costa and Vendeville 2002, Stockmal et al., 2007, Yin et al., 2011). In the latter cases, the frictional domain along the backstop was narrow, in the range of $5-10 \mathrm{~cm}$. In Model 2, the frictional internal domain was $60 \mathrm{~cm}$ long, which allowed for building a mature wedge before deformation reached the viscous silicone domain.

Finally, the design for Model 3 was more three-dimensional, as it included one lateral half that comprised an interbedded silicone layer, and one other half that has sand only (Fig. 2, bottom). In models that comprised a salt-analogue décollement (Models 2 and 3), we reduced the lateral friction between the upper sand layers and the lateral vertical glass walls by inserting a thin, vertical film of silicone between the sidewalls and the model itself (as in Costa and Vendeville, 2002; Couzens-Schultz et al., 2003; Santolaria et al., 2015).

\section{Terminology}

Figure 3 illustrates, for the sake of clarity, what we mean below in terms of shallow and deep thrusts. The deep thrusts root at depth into the lower décollement made of frictional glass microbeads. In contrast, the shallow or upper thrusts root into the viscous silicone layer embedded at mid height of the sedimentary cover.

\section{Experimental results}

Model 1, having only one potential frictional décollement at depth, deformed in a manner similar to previously published "classic" models of fold-and-thrust belts and accretionary prisms (Malavieille, 1984; Mulugeta and Koyi, 1987, and many authors), with a stable critical taper of about $8-10^{\circ}$, and 
(a) Model 1
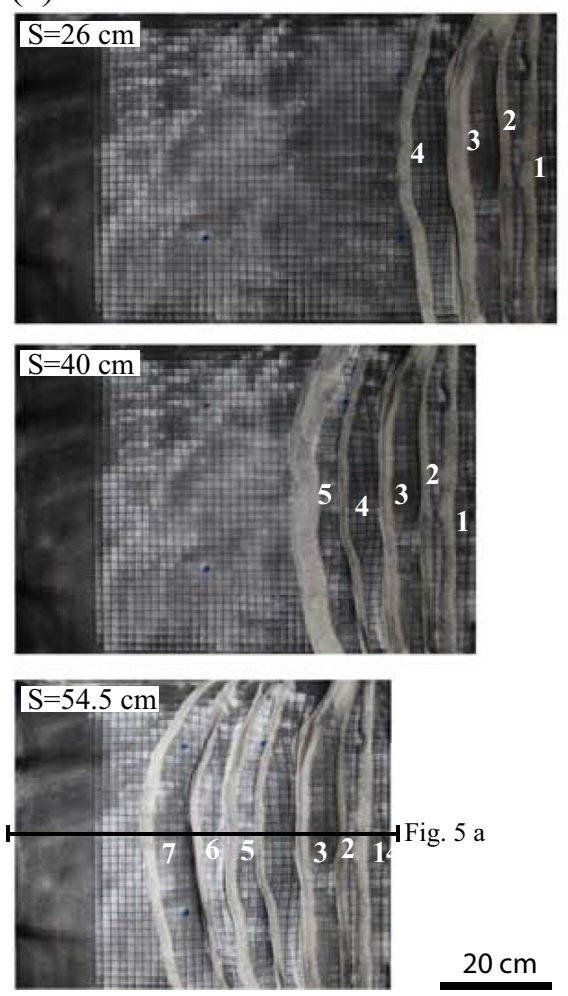

(b) Model 2
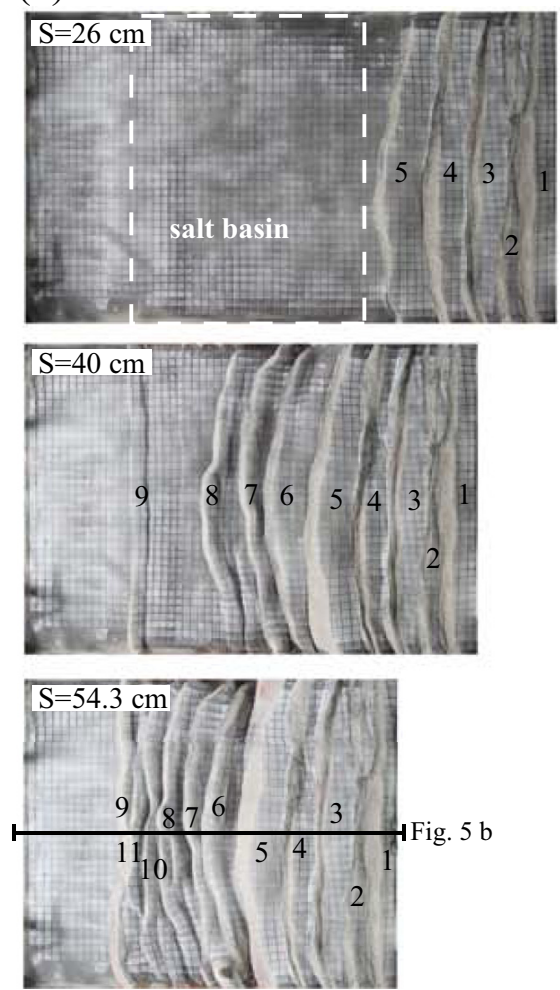

(c) Model 3
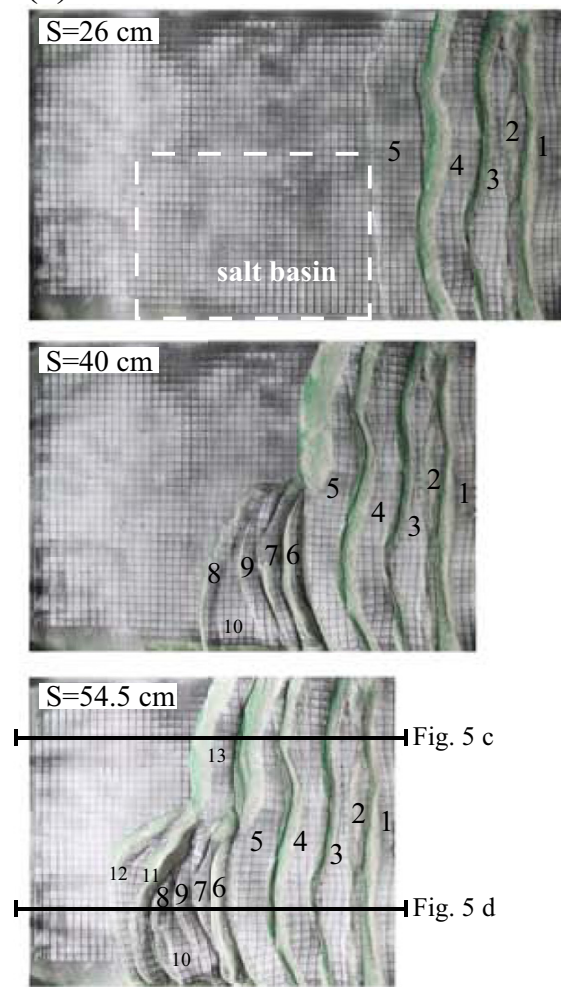

Fig. 4. Overhead photographs of Models 1, 2 and 3 during deformation, all at the same scale. The area comprising a salt-analogue décollement is outlined by white dashed lines. Black lines indicate the location of the cross sections shown in Figure 5. "S" stands for "shortening".

younger thrusts forming ahead of older ones, in a piggy-back fashion (Figs. 4A, 5A, and 6).

Model 2 had two distinct stages of evolution. First, the model evolved as Model 1 until the deformation front reached the hinterland pinch-out of the salt-bearing domain (formation of Thrust 6 in Figs. 4B, 5B, and 6). From that stage on, in the upper part of the overburden, the deformation front propagated forward fast (Thrusts 7 to 9 in Figs. 4B and 5B) and rapidly reached the foreland salt pinch out (as in Costa and Vendeville, 2002; Santolaria et al., 2015). However, at depth, no new thrust formed. The deep fold-and-thrust belt stopped propagating forward (Figs. 5B and 6), and all further shortening was accommodated by an unusually large amount of slip along Thrust 6 (which slid on the shallow salt weld; Figs. 5B and 6), and, to a less extent, by reactivating older thrusts ( 1 to 5 in Fig. 5B). With no doubt, the presence of a salt layer in the cover blocked the forward propagation of the deep fold-and-thrust belt. In addition, the overall surface slope angle (resulting from movement along both the upper and deep structures) was much lower than that in Model 1. Also, there is a sharp contrast in taper between the proximal area devoid of salt (a few degrees) and the distal area where salt was present (near zero degree).

In Model 3 (Fig. 4C, 5C and D, and Fig. 6), which had two different lateral compartments, the structural evolution varied along strike, and some amount of lateral influence occurred between the two compartments. In Model 3, just as in Model 2, the kinematics in both the upper and deeper series changed radically once the deformation front reached the salt-bearing region. As in Model2, deformation in the upper series propagated forward fast. At the same time, in the deeper series, the forward propagation of the deformation front slowed down dramatically in both the North (no salt; Fig. 5) and South (saltbearing) regions (Figs. 4C and Fig. 6). As in Model 2, it is the foremost thrust (here, Thrust 5 in Figs. 5D and 6) that accommodated most of the displacement, although one late thrust (Thrust 13) formed during the very latest stages of the experiment (Figs. 5D and 6). Laterally, this influenced the saltfree area by forcing the foremost basement thrust (Thrust 5 in Figs. 5C and 6) to remain active longer than usual before being replaced by Thrust 13 .

\section{Discussion/Conclusions}

The crucial observation about the evolution of the saltbearing models described above is that forward propagation of the deep thrust front is stopped, or at least drastically slowed down, once the deformation front reaches the hinterland salt pinch out. This pattern is well illustrated by the chart in Figure 6: before the deep deformation reaches the proximal salt pinch out, most of the thrusts have the same behavior and overall slip. From that stage on, even though deformation in the upper series propagates rapidly forward and quickly reaches the external salt pinch out, forward propagation of the deep deformation front appears to come to a stand still, and 

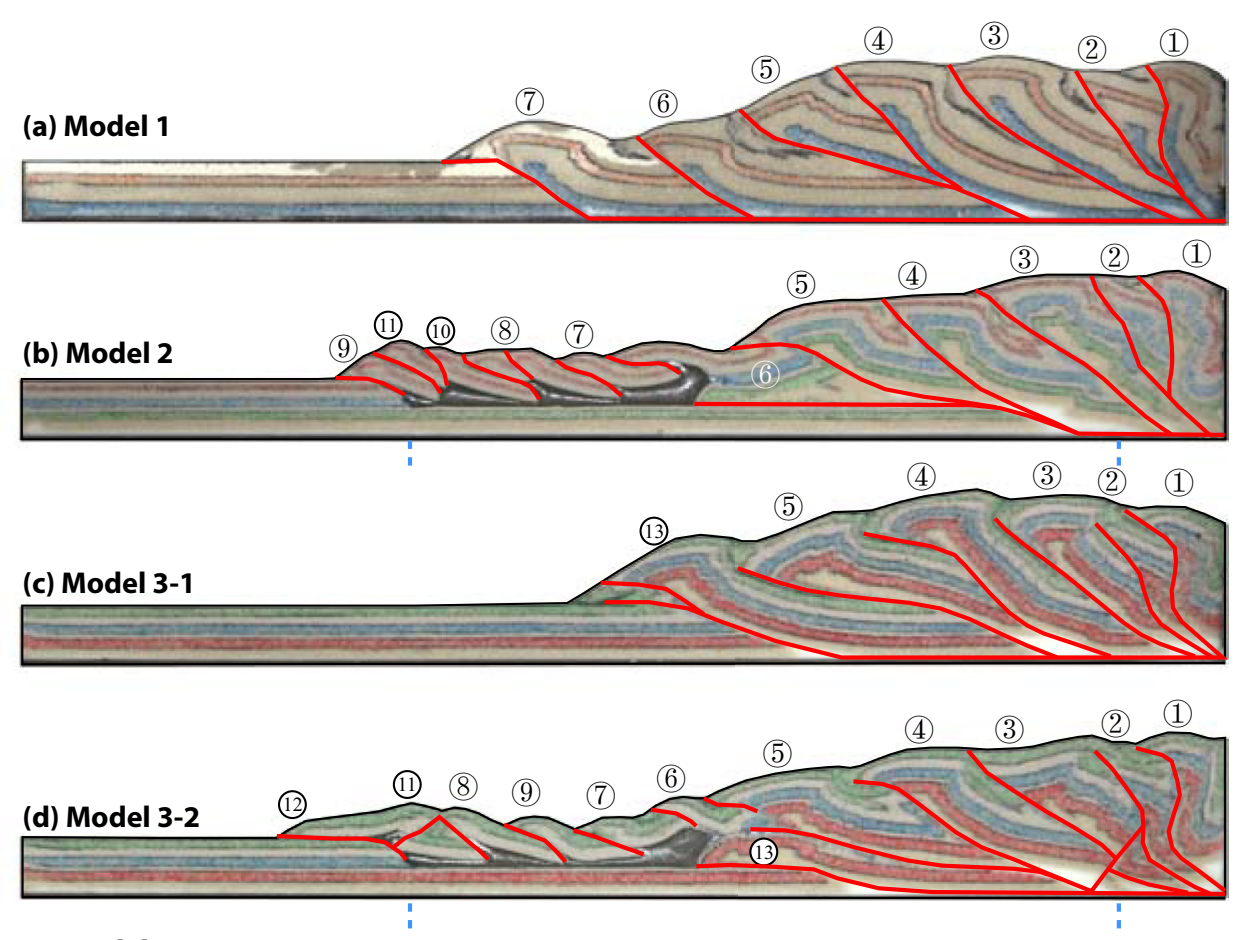

(e) Model 3

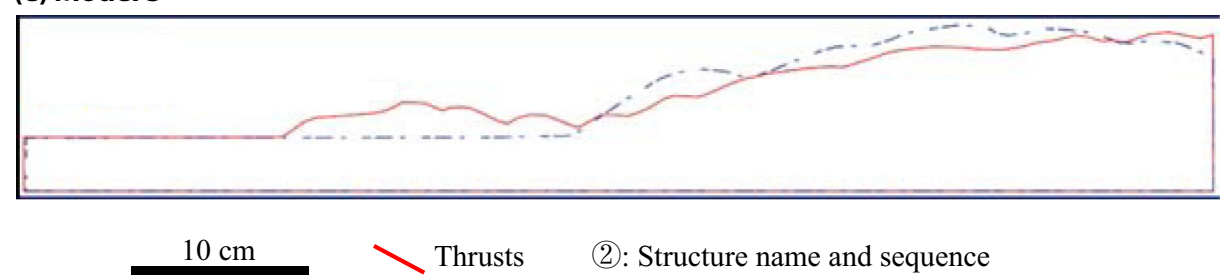

Fig. 5. Cross sections in all three models after deformation. Figures $5 \mathrm{C}$ and $\mathrm{D}$ are located outside and inside, respectively the salt-bearing area in Model 3. The blue dashed lines mark the initial position of the internal and external salt pinch outs. Figure 5E compares the topographic profiles of the two sections of Model 3 (Red: salt-bearing region; Blue: Salt-free region).

there, most of the subsequent regional shortening is accommodated, not by forming new thrusts ahead, but by continued long-lasting slip along the foremost deep thrust, and by reactivating the other thrusts. This, in turns allows for the vertical stacking of basement thrusts behind the hinterland salt pinch out. In another article (Borderie et al., 2018), we illustrate what would be the further evolution of such a system, a system where deformation in the hinterland progresses much longer, then all new basal thrusts are shorter and stack vertically one above the other, leading to a geometry similar to that of an asymmetric anticlinal stack.

Simple mechanical considerations can help explain this change in behavior. The ability of a fold-and-thrust belt to propagate forward depends on its capacity to build up enough gravitational energy by creating a surface slope in order to overcome the various stresses that resist its advance. In purely 2-D systems, such resistance comes only from the friction/ shear stress resistance exerted at the base of the system (Chapple, 1978; Suppe, 1981; Davis et al., 1983; Dahlen, 1990), and additional stresses if the detachment system is not horizontal (e.g., Koyi and Vendeville, 2003). Where the foldand-thrust belt detaches on an evaporitic layer, rocksalt's viscosity is so low that the critical surface slope is very gentle, near zero or so (Davis and Engelder, 1985; Cotton and Koyi, 2000; Costa and Vendeville, 2002; Storti et al., 2007), and the deformation front can rapidly propagate across the entire basin and reach the foreland salt pinch out.

In our models, the critical taper that was needed for the deep fold-and-thrust belt to propagate was about 8 to $10^{\circ}$ (based on Model 1's results). It is this topographic slope that allowed deformation to propagate forward. However, as soon as the deformation front reached the area where salt was present (Models 2 and 3), the overall topographic slope was no longer controlled by the ideal critical taper observed in the proximal region, but by that of the salt-bearing region. This means that the critical taper was much lower than that required for the deep fold-and-thrust belt to propagate. How the presence of a viscous décollement within the cover can affect a fold-and-thrust belt's topography is illustrated by the two profiles in Figure 5E, and also by a frontal photograph of Model 3 (Fig. 7). On this photograph, the topography in the salt-free area (left-hand side) is much higher than that in the salt-bearing region (right-hand side), as highlighted by the white topographic line.

In response to the lowering of the regional topographic slope once the deformation front reached the salt province, the 


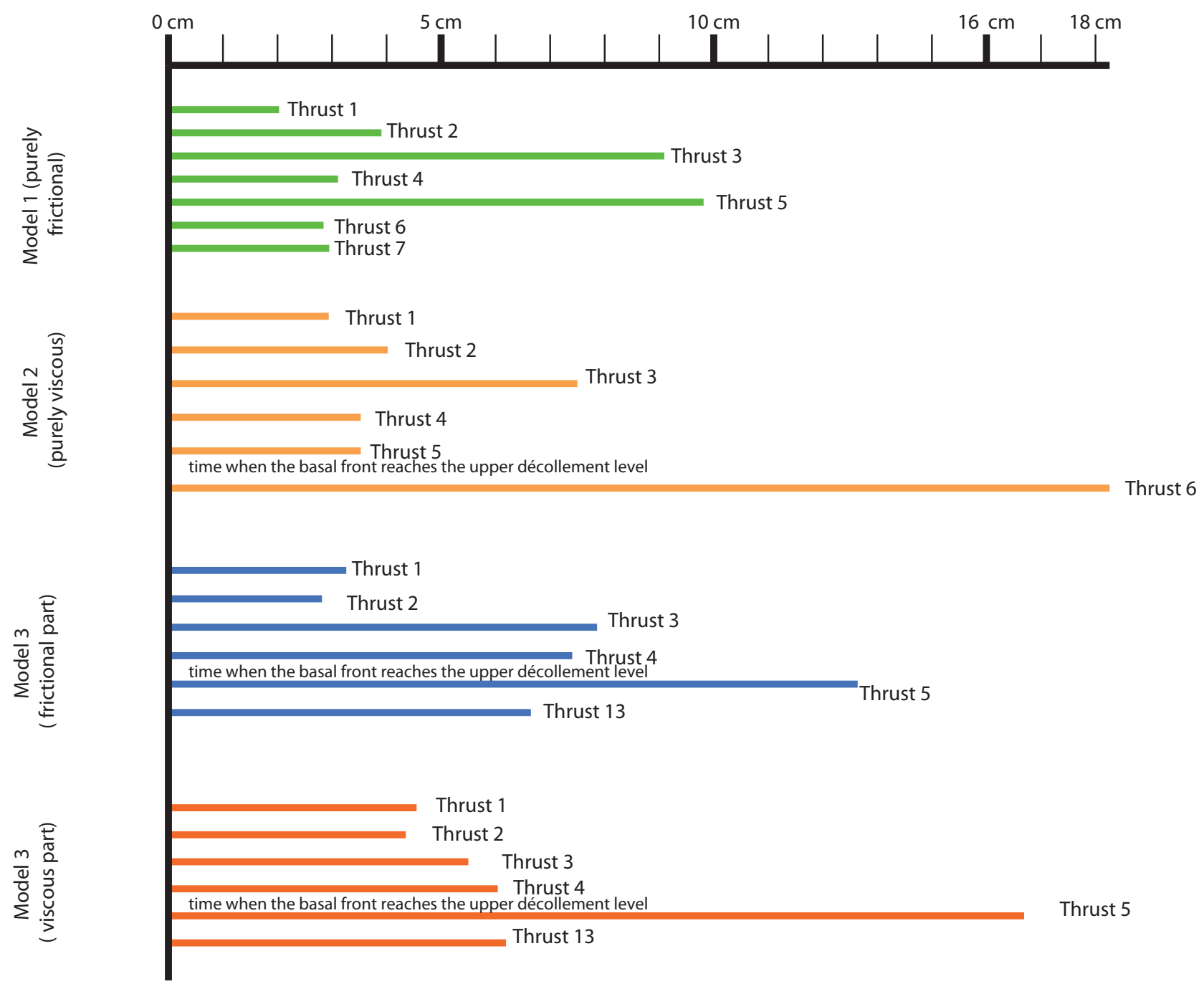

Fig. 6. Chart indicating the total displacement along each, basal, sub-salt thrust in each model (and two for Model 3, one in the frictional region, one in the viscous region). The chart illustrates that, at the final stage, fewer new thrusts formed when a viscous layer was interbedded in the cover. It also shows a similar pattern during the first part of the experiment, then a significant increase in total displacement along the frontal thrust once the front reached the area comprising an interbedded viscous layer (Thrust 6 in Model 2, Thrust 5 in Model 3). Note that even in the frictional half of Model 3, Thrust 5 had a significantly larger displacement than in the salt-free model (Model 1), which illustrates the lateral influence on the frictional region of the adjacent salt-bearing region.

deeper belt was no longer capable of propagating forward. Instead, it accommodated further shortening by continually activating the youngest thrust and by thickening the entire wedge behind. It has to be noted that the change in the slope angle is very abrupt and remains so even once the deep frontal thrust has ramped up to the salt-bearing décollement.

In some way, the influence of having salt within the cover is analogous to that of surface processes, such as erosion or sedimentation, that can alter the overall topographic slope (Konstantinovskaia and Malavieille, 2005; Graveleau et al., 2012) and can thereby impact the behavior of the underlying thrusts.

In other words, by imposing a low topographic taper, the presence of a salt décollement makes the forward propagation of the deep fold-and-thrust belt much more difficult, if not impossible and it does even influence the kinematics of thrusts located laterally outside the salt-bearing region.

\section{Supplementary Material}

The data files related to this manuscript are 6 short movie files from each of the three models showing their evolution in map and side views.

The Supplementary Material is available at https://www.bsgf. $\mathrm{fr} / 10.1051 / \mathrm{bsgf} / 2017202 / \mathrm{olm}$.

Acknowledgments. This work was funded by the Tarim Oilfied Company (Korla, China), a subsidiary of Petrochina. We also thank numerous colleagues for fruitful discussions, and two anonymous reviewers for their helpful comments. 


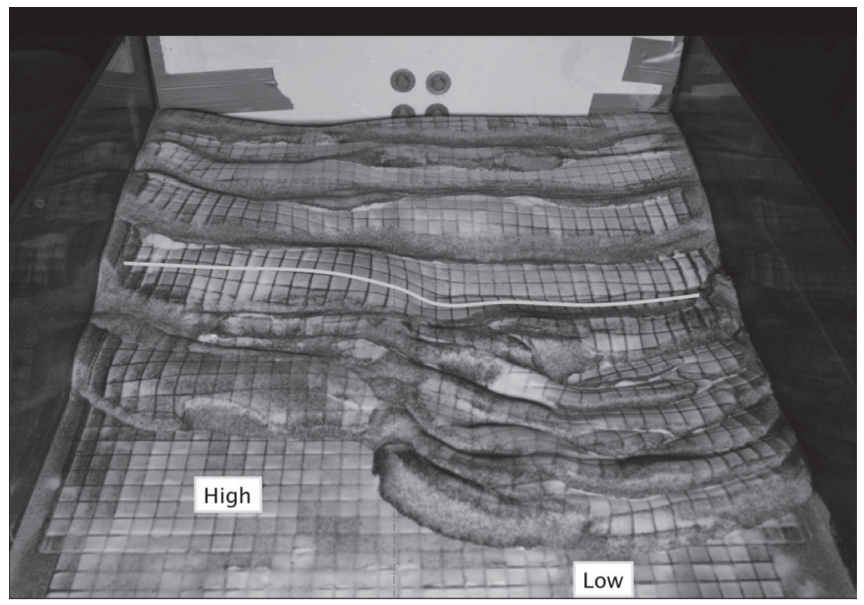

Fig. 7. Frontal view of Model 3 (looking toward the backstop). The left-hand side region has no viscous décollement, whereas the righthand side region comprises a viscous décollement embedded within the cover. Note the marked lateral change in topographic elevation across the model's width (thick white line). The scale is indicated by the $1.5 \mathrm{~cm} \times 1.5 \mathrm{~cm}$ passive markers printed on the model's surface.

\section{References}

Aitken JD, Pugh DC. 1984. The Fort Norman and Leith Ridge structures; major, buried, Precambrian features underlying Franklin Mountains and Great Bear and Mackenzie plains. Bulletin of Canadian Petroleum Geology 32 (2): 139-146.

Bonini M. 2003. Detachment folding, fold amplification, and diapirism in thrust wedge experiments. Tectonics 22 (6): 1065.

Borderie S, Graveleau F, Witt C, Vendeville BC. 2018. Impact of an interbedded viscous décollement on the structural and kinematic coupling in fold-and-thrust belts: Insights from analogue modeling. Tectonophysics 722: 118-137 (in press).

Chapple WM. 1978. Mechanics of thin-skinned fold-and-thrust belts. Geological Society of America Bulletin 89 (8): 1189-1198.

Chen S, Tang L, Jin Z, Jia C, Pi X. 2004. Thrust and fold tectonics and the role of evaporites in deformation in the Western Kuqa Foreland of Tarim Basin, Northwest China. Marine and Petroleum Geology 21 (8): 1027-1042.

Costa E, Vendeville BC. 2002. Experimental insights on the geometry and kinematics of fold-and-thrust belts above a weak, viscous evaporite décollement. Journal of Structural Geology 24 (11): 1729-1739.

Cotton J, Koyi H. 2000. Modeling of thrust fronts above ductile and frictional detachments: application to structures in the Salt Range and Potwar Plateau, Pakistan. Geological Society of America Bulletin 112 (3): 351-363.

Couzens-Schultz BA, Vendeville BC, Wiltschko DV. 2003. Duplex style and triangle zone formation: insights from physical modeling. Journal of Structural Geology 25 (10): 1623-1644.

Dahlen FA. 1990. Critical taper model of fold-and-thrust belts and accretionary wedges. Annual Review of Earth and Planetary Sciences 18: 55-99.

Davis D, Suppe J, Dahlen FA. 1983. Mechanics of fold-and-thrust belts and accretionary wedges. Journal of Geophysical Research 88 (B12): 1153-1172.

Davis DM, Engelder T. 1985. The role of salt in fold-and-thrust belts. Tectonophysics 119 (1-4): 67-88.
Duerto L, McClay K. 2009. The role of syntectonic sedimentation in the evolution of doubly vergent thrust wedges and foreland folds. Marine and Petroleum Geology 26 (7): 1051-1069.

Graveleau F, Malavieille J, Dominguez S. 2012. Experimental modelling of orogenic wedges: A review. Tectonophysics 538-540: $1-66$.

Guillier B, Baby P, Colletta B, Mendez E, Limachi R, Letouzey J, Specht M. 1995. Analyse géométrique et cinématique d'un "duplex" issu d'un modèle analogique visualisé en 3D par tomographie aux rayons X. Comptes Rendus de l'Académie des Sciences - Series IIA - Earth and Planetary Science Série 2a: Sciences de la Terre (321): 901-908.

Klinkmüller M, Schreurs G, Rosenau M, Kemnitz H. 2016. Properties of granular analogue model materials: A community wide survey. Tectonophysics 684: 23-38.

Konstantinovskaia E, Malavieille J. 2005. Erosion and exhumation in accretionary orogens: Experimental and geological approaches. Geochemistry, Geophysics, and Geosystems 6 (Q02006).

Koyi HA, Vendeville BC. 2003. The effect of décollement dip on geometry and kinematics of model accretionay wedges. Journal of Structural Geology 25 (9): 1445-1450.

Larrasoaña JC, Pares JM, Millan H, del Valle J, Pueyo EL. 2003. Paleomagnetic, structural and stratigraphic constraints on tranverse fault kinematics during basin inversion: the Pamplona Fault (Pyrenees, north Spain). Tectonics 22 (1071).

Leturmy P, Mugnier JL, Vinour P, Baby P, Colletta B, Chabron E. 2000. Piggyback basin development above a thin-skinned thrust belt with two detachment levels as a function of interactions between tectonic and superficial mass transfer: the case of the Subandean Zone (Bolivia). Tectonophysics 320 (1): 45-67.

Malavieille J. 1984. Modélisation expérimentale des chevauchements imbriqués: application aux chaînes de montagnes. Bulletin de la Société Géologique de France 7 (1): 129-138.

Morrell. 1995. Petroleum Exploration in Northern Canada: A Guide to Oil and Gas Exploration and Potential. N. O. a. G. D. I. a. N. A. Canada: 117.

Mugnier JL, Baby P, Colletta B, Vinour P, Bale P, Leturmy P. 1997. Thrust geometry controlled by erosion and sedimentation: a view from analogue models. Geology 25 (5): 427-430.

Mulugeta G, Koyi H. 1987. Three-dimensional geometry and kinematics of experimental piggyback thrusting. Geology 15 (11): 1052-1056.

Munoz JA. 2002. Alpine tectonics I: the Alpine system north of the Betic Cordillera tectonic setting; the Pyrenees. In: Gibbons Z, Moreno T, The Geology of Spain. London: Geological Society, pp. 370-385.

Nilfouroushan F, Pysklywec R, Cruden A. 2012. Sensitivity analysis of numerical scaled models of fold-and-thrust belts to granular material cohesion variation and comparison with analog experiments. Tectonophysics 526-529: 196-206.

Reston TJ, Fruehn J, von Huene R. 2002. The structure and evolution of the western Mediterranean Ridge. Marine Geology 186 (1-2): $83-110$

Rudolf M, Boutelier D, Rosenau M, Schreurs G, Oncken O. 2016. Rheological benchmark of silicone oils used for analog modeling of short- and long-term lithospheric deformation. Tectonophysics 684: 12-22.

Ruh JB, Kaus BJP, Burg J.-P. 2012. Numerical investigation of deformation mechanics in fold-and-thrust belts: Influence of rheology of single and multiple décollements. Tectonics 31 (3).

Santolaria P, Vendeville BC, Graveleau F, Soto R, Casas-Sainz A. 2015. Double evaporitic décollements: Influence of pinch-out 
overlapping in experimental thrust wedges. Journal of Structural Geology 76 (0): 35-51.

Serrano O, Delmas J, Hanot F, Vially R, Herbin J.-P, Houel P, Tourlière B. 2006. Le Bassin d'Aquitaine: valorisation des données sismiques, cartographie structurale et potentiel pétrolier. BRGM.

Sherkati S, Letouzey J, Frizon de Lamotte D. 2006. Central Zagros fold-thrust belt (Iran): New insights from seismic data, field observation, and sandbox modeling. Tectonics 25 (4).

Stockmal GS, Beaumont C, Nguyen M, Lee B. 2007. Mechanics of thin-skinned fold-and-thrust belts: insights from numerical models. Whence the mountains? Inquiries into the evolution of orogenic systems: a volume in honor of Raymond A. Price. J. W. Sears, T. A. Harms and C. A. Evenchick (Boulder, CO, USA), Geological Society of America Special Paper. 433: 63-98.
Storti F, Soto Marín R, Rossetti F, Casas Sainz AM. 2007. Evolution of experimental thrust wedges accreted from along-strike tapered, silicone-floored multilayers. Journal of the Geological Society, London 164: 73-85.

Suppe J. 1981. Mechanics of mountain building and metamorphism in Taiwan. Memoir of the Geological Society of China 4: 67-89.

Vergés J, Martínez A,Muñoz JA. 1992. South Pyrenean fold and thrust belt: The role of foreland evaporitic levels in thrust geometry. In: McClay KR, Thrust Tectonics. Chapman \& Hall, 255-264.

Yin H, Wang Z, Wang X, Wu Z. 2011. Characteristics and mechanics of Cenozoic salt-related structures in Kuqa foreland basin: insights from physical modeling and discussion. Geological Journal of China Universities 17 (2): 308-317.

Cite this article as: Vendeville BC, Pengcheng T, Graveleau F, Shaoying H, Wang X. 2017. How the presence of a salt décollement in the sedimentary cover influences the behavior of subsalt thrusts in fold-and-thrust belts, Bull. Soc. géol. Fr. $188: 37$. 